\title{
PREVENTIVE MAINTENANCE USING RELIABILITY CENTRED MAINTENANCE (RCM): A CASE STUDY OF A FERROCHROME MANUFACTURING COMPANY
}

\author{
S. Fore ${ }^{1}$ and A. Msipha ${ }^{2}$ \\ ${ }^{1}$ Department of Management \& Project Management \\ Cape Peninsula University of Technology, South Africa \\ fores@cput.ac.za \\ Production Engineering Institute \\ ${ }^{2}$ Scientific and Industrial Research and Development Centre (SIRDC), Zimbabwe \\ amsipha@sirdc.ac.zw
}

\begin{abstract}
High productivity in industry requires high equipment reliability and plant availability. The aim of this paper is to illustrate the management of preventive maintenance by application of the Reliability Centred Maintenance (RCM), targeting a ferrochrome processing plant. The research points out that preventive maintenance is often neglected, affecting process continuity, and thus compromising product quality due to drops and fluctuations in operating temperature. These breakdowns tend to be frequent and longer, thus affecting production targets. Start-up failures are also experienced after carrying out maintenance. The maintenance department is affected by the unpredictability of the equipment's operational patterns, and faces challenges in coming up with an effective spare part inventory management regime. This leads to crisis management, thereby increasing the direct cost of maintenance. RCM is used to create a cost-effective preventive maintenance strategy to address the dominant causes of equipment failure. The result is a maintenance programme that focuses scarce economic resources on those items that would cause the most disruption if they were to fail, and thereby increases production.
\end{abstract}

\section{OPSOMMING}

Industriële produktiwiteit word ten nouste beïnvloed deur uitnemende betroubaarheid en beskikbaarheid van aanlegtoerusting en vervaardigingstelsels. Hierdie navorsing is toegespits op die bestuur van voorkomende instandhouding (VI) met betroubaarheidsgedrewe instandhouding (BGI) by ' $n$ ferrochroomaanleg. Klem word daarop gelê dat VI dikwels geïgnoreer word wat daartoe lei dat produkgehalte verswak. Soos produksieonderbrekings toeneem, word vervaardigingsdoelwitte nie bereik nie vir verskeie redes. Die onderneming se instandhoudingsafdeling is gevolglik nie daartoe instaat om instandhouding doelmatig te verrig nie. Instandhoudingskoste neem ook toe.

BGI voorsien ' $n$ koste-effektiewe instandhoudingstrategie wat fokus op mislukkingsbelangrikheid waar fondse bestee moet word vir optimum aanlegbeskikbaarheid.

\footnotetext{
${ }^{1}$ Corresponding author

${ }^{2}$ The author was enrolled for a BTech (Production) degree in the Department of Production Engineering, Chinhoyi University of Technology
} 


\section{INTRODUCTION}

The company under study is a newly established ferrochrome smelting facility, commissioned in August 2005. The company operates a 2.5 MVA submerged electric arc furnace (SEAF). The product, ferrochrome, is destined for the export market. Ferrochrome is required by many industrialised countries for the aerospace, chemical, medical, and construction industries. It is also a major additive to steel in the production of various steel types, including universal stainless steel and high temperature resistant materials. Zimbabwean chrome, due to its superior quality (above $60 \%$ metallic chromium), is in high demand internationally. The market for the product is not yet close to saturation, due to its characteristics, which allow the maximum utilisation of steel, the most widely used industrial metal. The company has also managed to secure a niche market internationally, as shown by the demand for a product that is low in phosphorous impurities (less than $0.04 \%$ ), the only grade produced in Zimbabwe. The company therefore faces the challenge to increase output in order to supply more of the product to the customer. Ferrochrome production is a technically competitive industry, requiring the application of high technology equipment and expertise.

The most important production equipment is the submerged electric arc furnace. It is expected to run 24 hours a day without interruptions. The situation on the ground is different, however, as there are numerous breakdowns that affect process continuity, compromising the product quality due to drops and fluctuations in operating temperature. These breakdowns tend to be frequent and longer, thus affecting production targets. Startup failures are also experienced after carrying out maintenance. With the advent of loadshedding in Zimbabwe, this has become more pronounced, and availability has become more important. The maintenance department has been affected by the unpredictability of the equipment's operational patterns, such that there is always a shortage of key spare parts. This usually leads to panic-based operating charges, increasing the direct cost of maintenance.

Generally productivity requires high equipment reliability and an improvement in plant availability. The current availability is $75 \%$ against a world class target of greater than $97 \%$ [1]. The availability average in the process industry is $70 \%$ for the worst plants, $85 \%$ for other plants, while the world class standard is greater than 97\% [1]. The challenges associated with availability are directly linked to the fact that the SEAF is a breakthrough technology, having been designed, fabricated, and commissioned by the engineering team. Comparing the measured performance with world class performance highlights the gap, and so the journey towards improvement begins [2]. As a general observation, the closer any process plant is to world class, the greater its opportunity to improve. The first step to improving the performance and competitiveness of a plant is to benchmark it against the best in the world [1]. This has also led to modernisation, and the urgent need for high productivity has brought with it sophistication in equipment design. Wilson [3] and Kutucuoglu et al. [4] state that, because the change in manufacturing processes emphasises lean manufacturing, the reliability and availability of plant is crucial.

There is no constant pattern of availability at the study company. Besides the downtimes resulting from ineffective maintenance planning and strategies, power cuts brought by sporadic power load-shedding also affect process continuity. This has shown the need to utilise fully all available time for production. Furnace availability is therefore very important. Heiser and Render [5] indicate that maintenance performance is determined by employee involvement, maintenance procedures, and maintenance performance. Tsang et al. [6] say that maintenance measurement is needed in order to give a maintenance manager quantitative information on the extent to which maintenance goals can be reached, and on what action is to be taken in order to improve the operations to meet the goals. 


\subsection{Reliability centred maintenance - A definition}

ARMS reliability engineers say that an exact definition of RCM is still contested within the maintenance community. Because a straightforward definition of RCM is elusive, most attempts to explain the RCM concept to people who do not have a maintenance background are wordy, convoluted, and confusing. Smith [7] defines reliability as the probability that an item will perform a required function under stated conditions for a stated period of time. Moubray [8] defines RCM in two ways:

1. A process used to determine the maintenance requirements of any physical asset in its operating context.

2. A process used to determine what must be done to ensure that any physical asset continues to do whatever its users want it to do in its operating context.

IEC 60300-3-11[8] takes Moubray's definitions of RCM and comes up with one that defines RCM as a systematic approach for identifying effective and efficient preventive maintenance tasks for items in accordance with a specific set of procedures and for establishing intervals between maintenance tasks. Dunn [10] explains that effective maintenance helps to increase revenues by increasing equipment performance and plant capacity, which will in turn maximise the volume of sales.

\subsubsection{The history of RCM}

The history of RCM is well documented and well known to most maintenance practitioners. Most are well aware of the RCM methodology for developing maintenance plans, although a handful of different versions have very slightly different standard processes.

According to Nowlan and Heap [11], F. Stanley Nowlan and Howard F. Heap at United Airlines, under the Department of Defence in the United States, established the concept of RCM in 1978. The principles of RCM arose from a rigorous examination of certain questions that were often taken for granted. The questions are as follows:

1. How does a failure occur?

2. What are the consequences ?

3. What good can preventive maintenance do?

According to Nowlan and Heap [11], the RCM approach arose in the late 1960s and early 1970s when the increasing complexity of systems (and consequent increasing sise of the preventive maintenance task) forced a rethink of maintenance policies among manufacturers and operators of large passenger aircraft. United Airlines did pioneering work on the subject in the 1970s to support the development and licensing of the Boeing 747. This work showed that the failure modes of aircraft components are randomly distributed At this time aircraft maintenance was based mainly on flying hours; so a new method of maintaining aircraft was considered appropriate. The RCM approach assumes no prior knowledge of the components - a so-called zero-based or first principles approach. Each component in the aircraft was systematically analysed to identify its failure modes, and appropriate maintenance tasks were then assigned.

\subsubsection{Why use RCM?}

Sutton [12] explains that RCM does not contain any new principles for performing maintenance; it is a more structured way of using the best methods and disciplines. RCM governs the maintenance policy at the level of plant or equipment type. The strength of RCM is that it produces extraordinarily robust and effective planned maintenance programmes, even in situations where the development team have access to little or no historical data. Rausand [13] notes that RCM has been applied with considerable success for more than 20 years, first in the aircraft industry, and later in the military forces, the nuclear power industry, the offshore oil and gas industry, and many others. According to 
Campbell [14], if RCM is correctly applied, it can reduce the amount of routine maintenance work by a significant margin. Smith [15] also states that the benefits and advantages of using RCM are several, and have an impact on operations, safety, logistics, configuration, and administration.

\section{Advantages:}

1. It can be the most efficient maintenance programme

2. It lowers costs by eliminating unnecessary equipment maintenance

3. It minimises the frequency of overhauls

4. It reduces the probability of sudden equipment failures

5. It focuses maintenance activities on critical system components

6. It increases component reliability

7. It incorporates root cause analysis

\section{Disadvantages :}

1. It can have significant start-up costs associated with staff training and equipment needs. According to Bowler [16], underestimating these costs has led in many cases to the withdrawal of management support, resulting in the unsuccessful introduction of RCM.

2. Its savings potential is not readily seen by management.

\section{THE RCM METHOD}

The NASA paper on the use of RCM as the foundation of an efficient and reliable overall maintenance strategy suggests that Reliability-Centered Maintenance (RCM) is the optimum mix of reactive, time- or interval-based, condition-based, and proactive maintenance practices. As is shown in Figure 1, all maintenance approaches are used. The NASA paper further explains that, instead of being applied independently, these principal maintenance strategies are integrated to take advantage of their respective strengths, in order to maximise facility and equipment reliability while minimising life-cycle costs. The important point is that all these techniques play their part in an integrated maintenance philosophy.

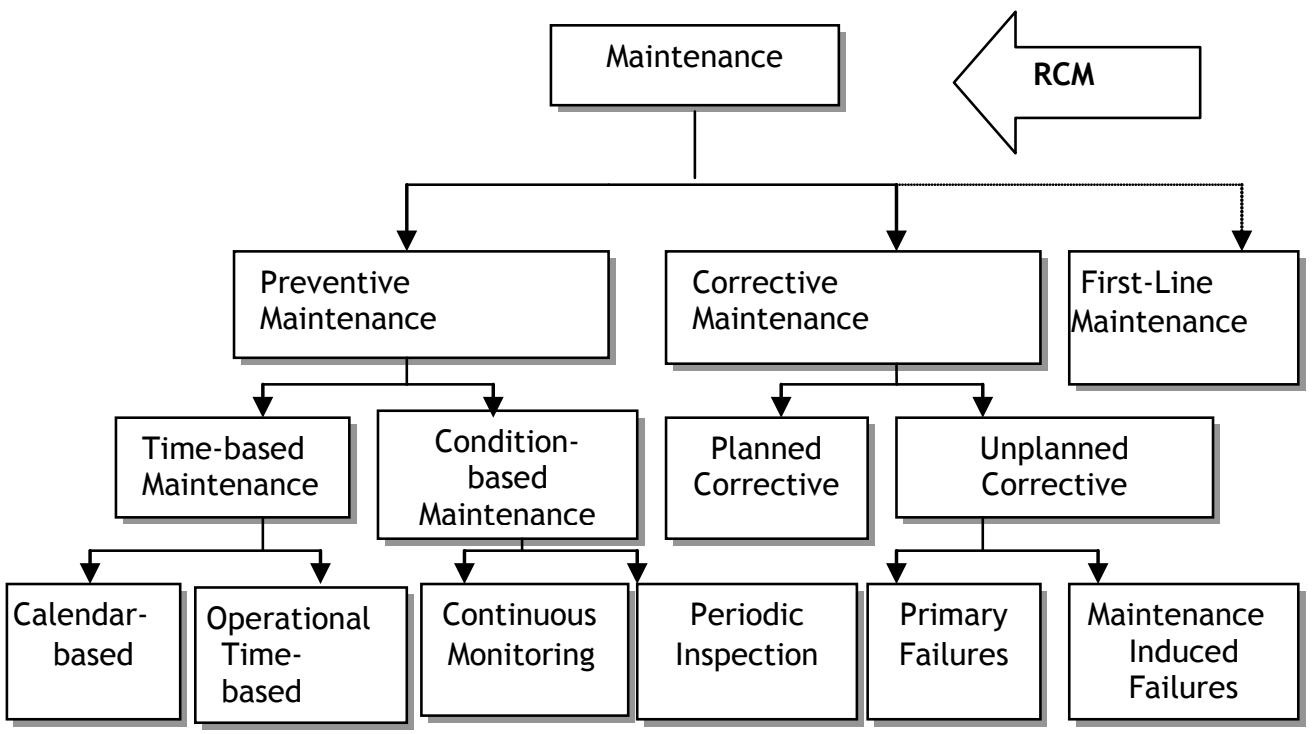

Figure1: Components of RCM programme (adapted from Det Norske Veristas, n.d)

Smith and Hinchcliffe [17] suggest that the RCM method can be described in terms of four unique features. These are the principles and the characteristics that define RCM: 
1. Preserve functions.

2. Identify failure modes that can defeat the functions.

3. Prioritise function need, via the failure modes.

4. Select only applicable and effective preventive maintenance tasks.

\subsection{Assets and criticality determination}

According to Moubray [8], RCM requires that, before setting out to analyse the maintenance requirements of assets in any arganization, it is necessary to know what these assets are and to decide which ones are to be subjected to the RCM process. Moubray [18] says that the process starts by preparing a comprehensive plant register. He defines the plant register as a list of all plant equipment and buildings owned or used by the rrganization that require maintenance of any sort. After establishing the assets through the asset register, RCM sets out to establish critical assets and those that need to be subjected to the RCM process. The $A B C$ analysis works well to establish the critical assets: it ranks values versus volume, where $20 \%$ of the plant assets may be high value assets occupying a small section of the plant, and whose breakdown has a more adverse impact on safety and operations, compared with the other $30 \%$ (medium value) and $50 \%$ (low value) assets.

\subsection{The seven basic questions}

Moubray [8] explains that the RCM process entails asking seven questions about the asset or system under review. The questions are as follows:

1. What are the functions and associated performance standards of the asset in its present operating context?

Moubray [8] categorises the functions as follows:

- Primary functions, which summarise why the asset was acquired in the first place. This category of functions covers issues such as speed, output, carrying or storage capacity, and product quality and customer service.

- Secondary functions, which recognise that every asset is expected to do more than simply fulfill its primary functions. Users also have expectations in areas such as safety, control, containment, comfort, structural integrity, economy, protection, efficiency of operation, compliance with environmental regulations, and even the appearance of the asset.

2. In what ways does it fail to fulfill its functions (failure mode)?

SAE JA1011 "Evaluation Criteria for RCM Processes" indicates that the failure modes to be considered are:

- Failures that have previously occurred on the equipment or similar machines.

- Possible failures that have not occurred before, but could have serious consequences.

- Failure modes for which preventive maintenance has already been undertaken in order to prevent failure.

\section{What causes each functional failure?}

Each potential failure must be investigated to identify every possible cause. Maintenance actions are then put in place to tackle the causes and not the symptoms of a failure. This stage of RCM must be controlled, as time can be wasted investigating unlikely causes of failure.

\section{What happens when each functional failure occurs?}

This step entails failure effects, which describe what happens when each failure mode occurs. Moubray (1997) states that these descriptions should include all the information needed to support the evaluation of the consequences of the failure [8]. 


\section{In what way does each failure matter?}

According to Moubray (1997), the greatest strength of RCM is that it recognises that the consequences of failure are more far-reaching than their technical characteristics [8]. Once the failure consequences have been identified, they are categorised, which aids in the determination of an appropriate maintenance task. Moubray categorises the consequences as:

- Hidden failure consequences, which have no direct impact but expose the organisation to multiple failures with serious, often catastrophic, consequences.

- Safety or environmental consequences: these failures hurt or kill someone. Environmental consequences breach corporate, regional, national, and environmental standards.

- Operational consequences, which affect production (output, product quality, customer service, or operating costs, in addition to the direct cost of repair).

- Non-operational consequences: evident failures that involve direct repair costs.

6. What can be done to predict or prevent each failure?

The characteristics of the individual failure mode will determine which one of the maintenance strategies will be chosen.

7. What should be done if a suitable proactive task cannot be found?

An obvious maintenance task may not exist for some failure modes. RCM provides a detailed decision tree to ensure that the correct type of maintenance task is selected for each failure mode.

\subsection{Problem Statement}

The average availability of equipment is currently at 75\%, against a world class standard of greater than 97\% [1]. Equipment availability is generally poor; and this has been emphasised in production meetings when it has been realised that the plant is not operating to expectations because it is usually unavailable for the time when it is required for production. According to Murty and Naikan [19], the rate of production, and hence net profit, is a function of plant or machinery availability. The availability of a plant has a direct effect on the net produce.

\subsection{Research aim and objectives}

\subsubsection{Aim}

The aim of the research is to improve plant availability. Patton [20] defines 'availability' as the probability that an item, under the combined influence of its reliability, maintainability, and maintenance support, will be able to fulfil its required function over a stated period of time, or at a given point in time.

\subsubsection{Objectives}

The objectives are as follows :

1. To increase availability from $75 \%$ to $85 \%$.

2. To increase production from 180 to 300 tonnes of alloy per month.

3. To reduce maintenance costs by $20 \%$ of the total manufacturing costs.

\section{PROCESS ANALYSIS}

A brief overview of the ferrochrome industry and the ferrochrome process is given below.

\subsection{The process flow}

Figure 2 below illustrates the processes involved in the manufacture of high carbon ferrochrome alloy. The raw materials used in the process are: 
1. Chrome ore from the Great Dyke and the Oliken mines in Ngezi.

2. Coke breeze from Ziscosteel coke breeze dumps.

3. Quartz from a quartz quarry 7 kilometres away.

The process involves mixing these materials in their correct amounts into an appropriate blend that will efficiently produce the required alloy in terms of the percentages of chromium, carbon, and silicon content.

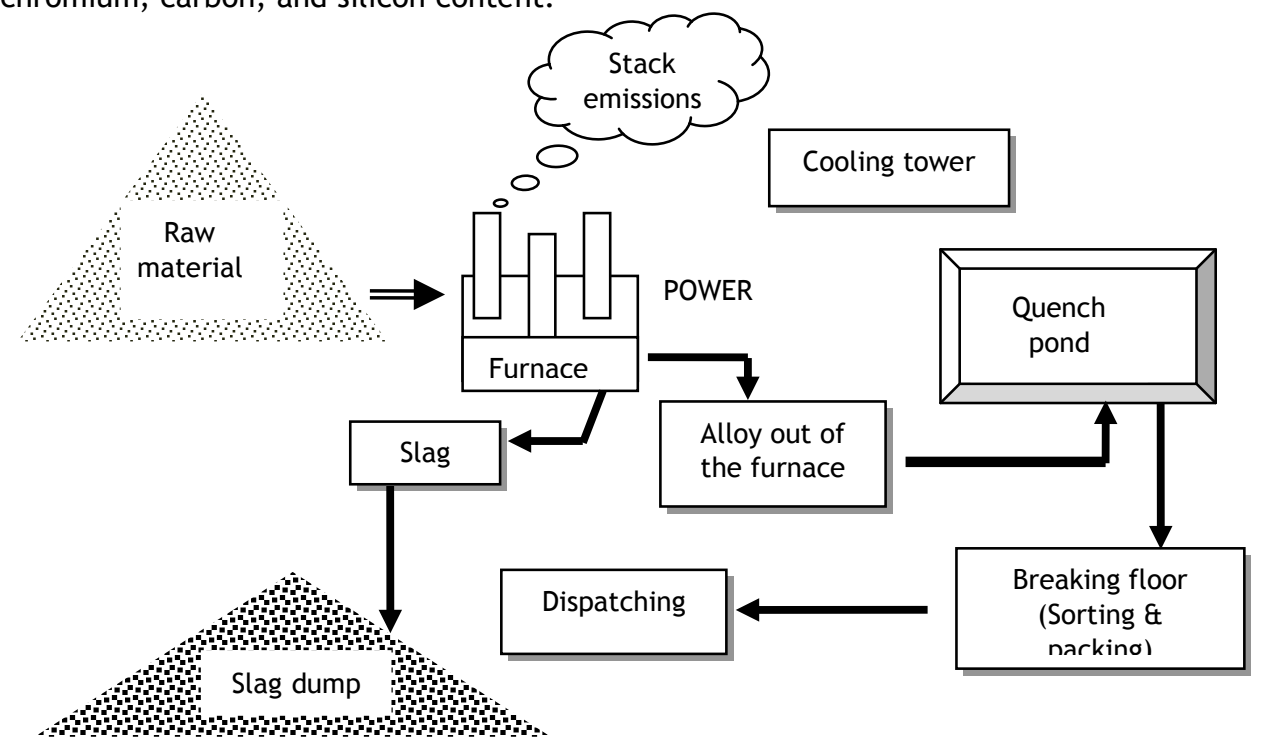

Figure 2: Schematic process flow chart

All the furnace operations are controlled from the control room, where the different meters for the furnace variables are housed. The operator is tasked to maintain furnace conditions by controlling the power through the electrodes. The resistance of the charge to high amperage current provides the heat. When enough power has been put into the furnace, and the slag has reached the right temperature - usually between $1600^{\circ} \mathrm{C}$ and $1680^{\circ} \mathrm{C}$ - the charge melts: the heavier liquid sinks to the bottom while the slag floats on top. Tapping of the furnace commences. This is the process of drawing the molten alloy and slag out of the furnace. The molten metal is drawn from the furnace by a process of oxygen lancing. This involves use of lance tubes, connected to an oxygen source. The oxygen clears off obstacles in the tap hole and tapping bars are then used for ram opening. The process employs the cascade technique when casting alloy from the furnace. Casting beds are prepared, from which the molten alloy and slag is allowed to flow. The molten alloy and slag are left to solidify, and the solidified ingots are stripped off the casting beds into quenching ponds for further cooling. The slag is put in the slag bunker for temporary storage before being taken to the slag dumps. The cooled ingot is machined, weighed and sent to the breaking floor for breaking, sizing, sorting, and bagging. Different material handling equipment is used when transporting the raw materials and the product. The availability of the material handling equipment is also vital to the process. Table 1 lists the material handling equipment available at the plant. The company hires trucks to transport the alloy to various customers.

\subsection{The submerged electric arc furnace}

This is the most crucial piece of equipment. The furnace is expected to operate continuously for 24 hours in a day. However, this is not the case on the ground. Numerous breakdowns occur on the furnace, undermining the availability of the equipment. The furnace consists of different mechanical and electrical components. Failure in one component means stopping the whole plant. The company relies entirely on the furnace 
operations for its production. Therefore each part on the furnace is critical in its own right. Figure 3 below illustrates the power flow route. This represents the important components on the furnace.

\begin{tabular}{|l|l|}
\hline Handling equipment & \multicolumn{1}{|c|}{ Uses } \\
\hline Trucks & Transport raw material to the plant \\
& 1. Ores from the mine \\
& 2. Coke from Ziscosteel \\
\hline Forklifts & Used around the plant for \\
& 1. Stripping alloy and slag from casting beds \\
& 2. Transporting the alloy and slag into casting beds \\
& 3. Loading and offloading trucks \\
\hline Overhead crane & Transporting alloy and slag from the quench ponds to the \\
& breaking floor \\
\hline Mobile crane & Transporting slag from the slag bunker to the slag dumps \\
\hline
\end{tabular}

Table 1 : Material handling equipment

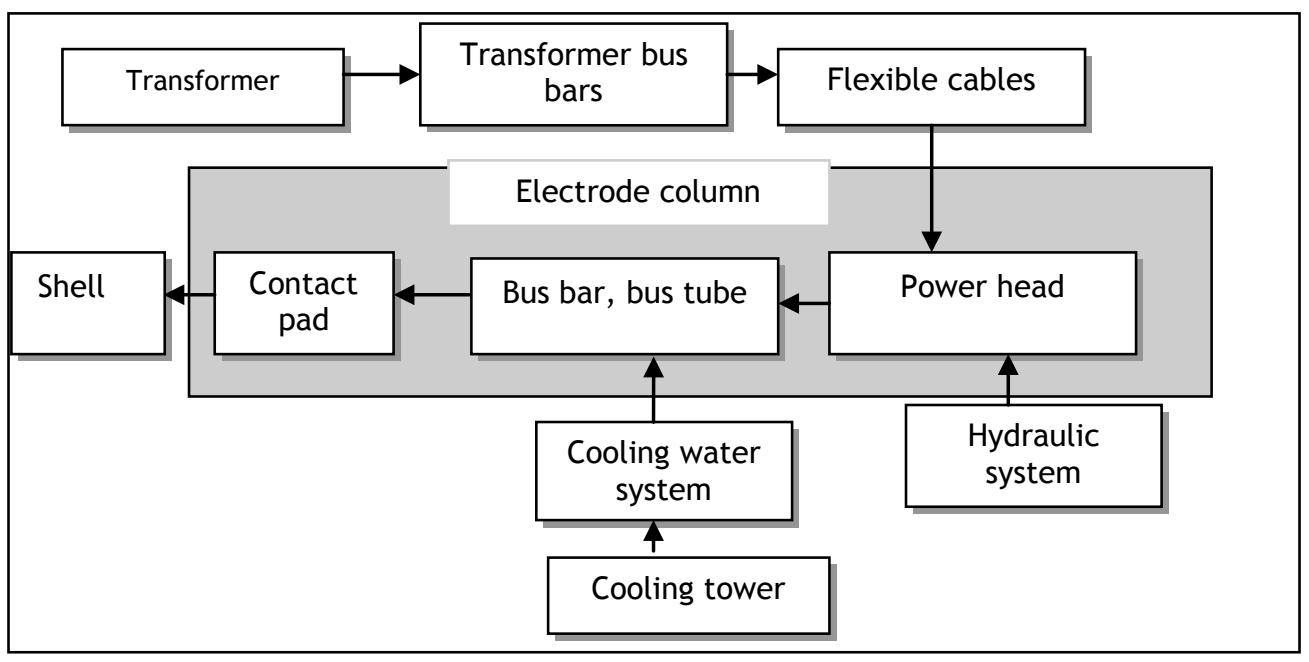

Figure 3: OFA power route

It is around these components - which constitute the power route - that maintenance is generally centred. The high temperatures involved in the operation of furnaces mean that the level of maintenance required is intense.

\subsection{The furnace transformer}

There is an $8,500 \mathrm{KVA}$ rated furnace transformers, to which are connected transformer bus bars. The transformer consists of oil cooler and an oil pump. The furnace operates at 2.5 MVA, which means that the transformer is operating at $30 \%$ of its capacity.

\subsection{The electrode column}

Three identical electrodes constitute the electrode column. Flexible cables connect the electrode column to the transformer, and these are coupled to the power head. The head is therefore the part of the furnace that receives electrical current. Connected to the power head is the hydraulic system, consisting of the hydraulic power pack, hydraulic cylinder, pipes, and hoses. During operation the electrode column is raised and lowered using the hydraulic system.

Bus bars and bus tubes connect the furnace head to the contact pads, which hold the electrode in position. The electrode consists of a casing made from $3 \mathrm{~mm}$ steel sheets and 
electrode paste. The electrode burns off during operation; therefore to supplement it, a casing and electrode paste are added to the column. This process of casing and paste addition is expected to take 10 minutes, and is done with the furnace switched off. When a casing has been added, the electrode is slipped so that a one metre length of the electrode is maintained from the contact pads into the furnace burden. Slipping is done by loosening the contact pad bolts and lowering the electrode, using the hydraulic system.

\subsubsection{Cooling water system}

Contact pads are subject to extreme heat during operation. A cooling water system is used to facilitate the cooling of the contact pads. This system consists of a cooling tower, a chute into which the water flows, water pipes and hoses, and temperature and pressure gauges that give information on the condition of the water.

\subsubsection{The furnace shell}

All raw materials in the smelting process are fed into the furnace shell. This is also where the electrodes are immersed. The furnace shell is made up of refractory lining. Of major importance is the point where the tap hole is positioned. This area is vulnerable to breakouts, which is why the refractory lining must always be maintained.

\section{CURRENT PATTERNS}

Data used in this analysis was derived from monthly production reports. The data from October 2006 to March 2007 has been used because it is the most recent data to have been accurately captured, and thus is more reliable and makes sense.

\subsection{Availability}

Availability is the most important part of operations. The availability of the furnace is calculated from the formula given by Koshal [21] as:

$$
A=\frac{(\text { Possible Operating Time })-(\text { Downtime })}{\text { Possible Operating Time }}
$$

The targeted availability is $85 \%$, against a world class standard of greater than $97 \%$. The target of $85 \%$ was chosen arbitrarily to initiate the drive towards the world class standard.

The availability patterns for the furnace are summarised in table 2 below. There is no constant pattern of availability. The month of December had the worst availability, with a standard deviation of 25 .

\subsection{Production}

Production is based on out-of-furnace (OOF) alloy production. The target OOF alloy at $85 \%$ availability is 12 tonnes a day. Some of the alloy is lost to the slag; therefore the alloy recovery percentage is $90 \%$, bringing the targeted alloy to 75.6 tonnes a week.

\begin{tabular}{|c|c|c|c|c|c|c|c|c|}
\hline \multirow{2}{*}{$\begin{array}{c}\text { Month } \\
(2006-2007)\end{array}$} & \multicolumn{5}{|c|}{ \% Availability } & \multirow[b]{2}{*}{ STD } & \multirow[b]{2}{*}{ Target } & \multirow[b]{2}{*}{ Variance } \\
\hline & $\begin{array}{c}\text { Week } \\
1\end{array}$ & $\begin{array}{l}\text { Week } \\
2\end{array}$ & $\begin{array}{l}\text { Week } \\
3\end{array}$ & $\begin{array}{c}\text { Week } \\
4\end{array}$ & $\begin{array}{l}\text { Week } \\
5\end{array}$ & & & \\
\hline October & 62.63 & 58.63 & 48.21 & 55.04 & 56.13 & 5.97 & 85 & 35.9 \\
\hline November & 67.29 & 70.8 & 61.51 & 74.65 & 68.56 & 5.58 & 85 & 23.4 \\
\hline December & 37.64 & 60.39 & 75.09 & 18.33 & 47.86 & 25.0 & 85 & 44.1 \\
\hline January & 84.93 & 82.37 & 84.71 & 84.9 & 84.23 & 1.24 & 85 & 7.8 \\
\hline February & 79.46 & 79.61 & 87.1 & 78.8 & 81.24 & 3.92 & 85 & 10.8 \\
\hline March & 80.17 & 78.98 & 82.6 & 79.61 & 80.34 & 1.58 & 85 & 11.6 \\
\hline
\end{tabular}




\begin{tabular}{|l|r|r|r|r|r|r|r|r|}
\hline \multirow{2}{*}{$\begin{array}{l}\text { Month } \\
\text { 2006-2007 }\end{array}$} & $\begin{array}{c}\text { Week } \\
1\end{array}$ & $\begin{array}{c}\text { Week } \\
\mathbf{2}\end{array}$ & $\begin{array}{c}\text { Week } \\
\mathbf{3}\end{array}$ & $\begin{array}{c}\text { Week } \\
\mathbf{4}\end{array}$ & Average & STD & $\begin{array}{c}\text { Target/ } \\
\text { (tonnes) }\end{array}$ & $\begin{array}{c}\text { Variance } \\
\text { (Target- } \\
\text { average) }\end{array}$ \\
\hline October & 40.2 & 35.8 & 45.7 & 53.5 & 43.8 & 7.63 & 75.6 & 31.8 \\
\hline November & 29.8 & 39.47 & 31 & 43.6 & 35.97 & 6.66 & 75.6 & 39.6 \\
\hline December & 16.7 & 27.97 & 48.43 & 6.5 & 24.9 & 17.97 & 75.6 & 50.7 \\
\hline January & 55.96 & 55.11 & 57.82 & 57.08 & 56.49 & 1.2 & 75.6 & 19.1 \\
\hline February & 57.62 & 52.75 & 69.25 & 54.28 & 58.48 & 7.47 & 75.6 & 17.1 \\
\hline
\end{tabular}

Table 3: Production patterns

\begin{tabular}{|l|r|r|r|r|}
\hline $\begin{array}{l}\text { Month } \\
\text { 2006-2007 }\end{array}$ & $\begin{array}{c}\text { Alloy dispatches } \\
\text { (tonnes) }\end{array}$ & \multicolumn{1}{c|}{ Target } & \multicolumn{1}{c|}{ Variance } & \multicolumn{1}{c|}{ Variance } \\
\hline October & 140 & 224 & 84 & 37.5 \\
\hline November & 140 & 224 & 84 & 37.5 \\
\hline December & 140 & 224 & 84 & 37.5 \\
\hline January & 224 & 336 & 112 & 33 \\
\hline February & 224 & 336 & 112 & 33 \\
\hline March & 196 & 336 & 140 & 41.7 \\
\hline
\end{tabular}

Table 4: Dispatch records

Table 4 above shows the alloy that was dispatched to the customer. A load consists of 28 tonnes of alloy. The percentage alloy recovery of the furnace is $90 \%$. There is a direct relationship between the OOF alloy production and the alloy dispatched to the customer. It should be noted that, for the company to remain in business, it must dispatch as much of the alloy as possible to the customer. The breakeven point is 8 loads of alloy per month, equivalent to 224 tonnes of sales volume. One load represents revenue gains of US\$20,370.00.

\subsubsection{Composition of total downtime}

It can be established that there is a direct relationship between availability and production. Because of this, the downtime warranted further analysis. The downtime was found to consist of the following:

1. Maintenance: this constitutes both mechanical and electrical repairs to be carried out on the furnace.

2. Production-related: this is the time when the production personnel perform production-related tasks like slipping, casing addition, removing broken electrodes (stubs), and pasting.

3. Materials shortage: the company has a subsidiary that is responsible for supplying ore to the furnace. Logistical problems mean that there is usually a shortage of ore at the plant, forcing the furnace to low load or even to switch off. Other raw materials for the furnace - such as imported lancing tubes and electrode paste - are usually out of stock because of late deliveries.

4. Power cuts: this was a major contributor to downtime, owing to the countrywide loadshedding. The pie chart in Figure 4 illustrates how these factors contributed to furnace downtime. 


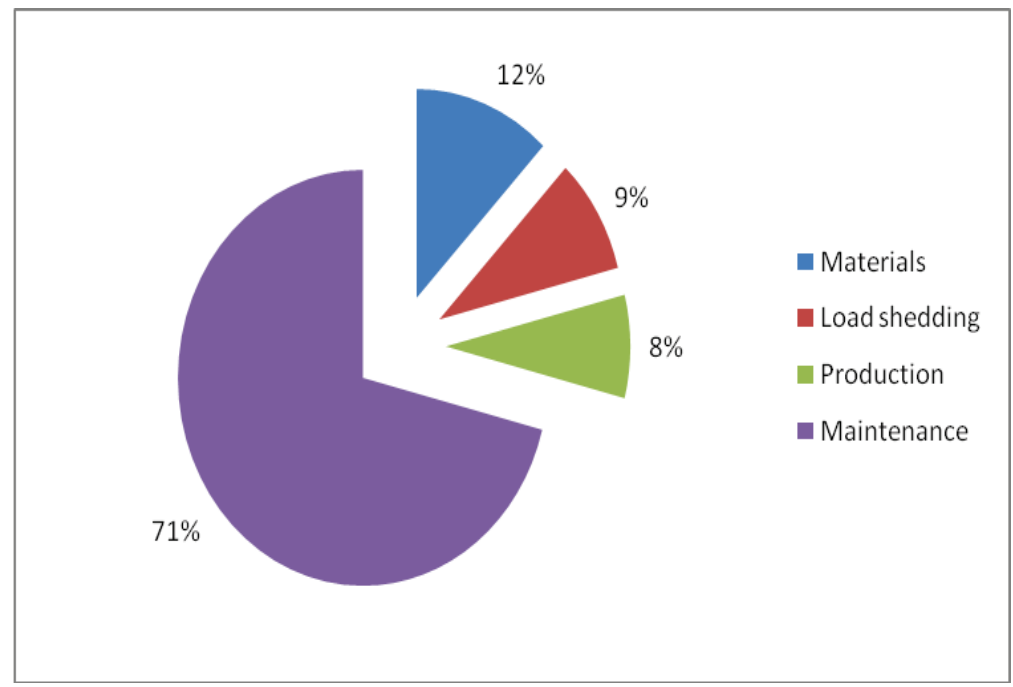

Figure 4: Downtime composition

The pie chart shows that maintenance causes $71 \%$ of the total furnace downtime. Availability is therefore a function of maintenance. Against this background, maintenance requires further analysis.

\subsection{Maintenance costs}

The costs incurred when maintaining the furnace equipment were analysed for December 2006 and January 2007 because data for these two months was readily available. Maintenance costs contributed $22.6 \%$ and $11.5 \%$ of the total production costs for the months of December 2006 and January 2007 respectively. For December 2006, the expenditure on maintenance was $Z \$ 10,152,022.12$, compared with $Z \$ 6,184,525.58$ in January 2007 . The maintenance cost for October 2007 to January 2008 averaged Z\$6,000,000 a month after implementation of the initial RCM steps.

\subsection{The maintenance department}

The maintenance department is tasked to ensure that all the equipment is available at the time when the operators require it.

\subsubsection{Maintenance policy}

The maintenance policy has a direct bearing on the efficiency and the economy of the plant. It determines the type of organisational structure and the type of maintenance strategies to be employed on the equipment. From interviews conducted, it was found that the company has no maintenance policy, and that most of the workforce does not know about such policies.

\subsubsection{The maintenance team}

The maintenance organisation consists of the plant engineer as the top person, supported by the engineering supervisor and the engineering charge hand. There is one electrical artisan, one boilermaker, one fitter artisan, and one bricklayer. The four forklift operators are also part of the maintenance or engineering team. The maintenance team has fifteen members, including the artisan assistants.

The company culture is to react to failures, fix broken equipment, and respond to call-outs. Interviews revealed that little or no training was arranged for the maintenance team, but 
that several visits were made to other organisations, such as the Zimbabwe Alloys Company, to assess their maintenance operations. Records showed that there was no budget for maintenance training. While consulting on RCM, the researcher found that all key maintenance personnel had heard of RCM, but were not sure how it could benefit them.

\subsubsection{The maintenance strategy}

From the maintenance reports, the researcher established that breakdown maintenance was mostly practised. Breakdown maintenance was practised from the day of commissioning the plant until January 2007, when a planned maintenance strategy was introduced. The maintenance or engineering crew performed the maintenance activity only when there was an anomaly in the system. Once a work order has been raised for a job to be done, a maintenance job card is filled in on completion of the task. The maintenance records show that there is poor recording of maintenance tasks done on equipment. The information is inaccurate, revealing lack of accountability - especially on spares used and time taken to finish the repair. When interviewed, the operators and the artisans acknowledged that they knew how to complete the job cards, and that the problem was mainly one of negligence. It was also found that there are maintenance checklists for the plant equipment, but these are usually filled in incorrectly, and are hardly ever used by the maintenance personnel.

When interviewed, the plant engineer stated that the company had no asset register. An asset register is important because it provides information on each item in the plant. With a list of all these items, it is easy to determine those that require maintenance and to schedule the maintenance activities accordingly. The assets that are critical to the operations are also easily determined. With an asset register, it is also easy to optimise the inventory for the different plant spares.

The research also showed that the plant spares inventory is chaotic. There are usually costs associated with buying spares in a rush. The maintenance or spare parts inventory is not controlled. This is usually shown by the unavailability of spares when required.

\section{RESULTS AND DISCUSSIONS}

\subsection{Availability and production}

Patton [20] defines availability as the probability that an item, under the combined influence of its reliability, maintainability, and maintenance support, will be able to fulfil its required function over a stated period of time, or at a given point in time.

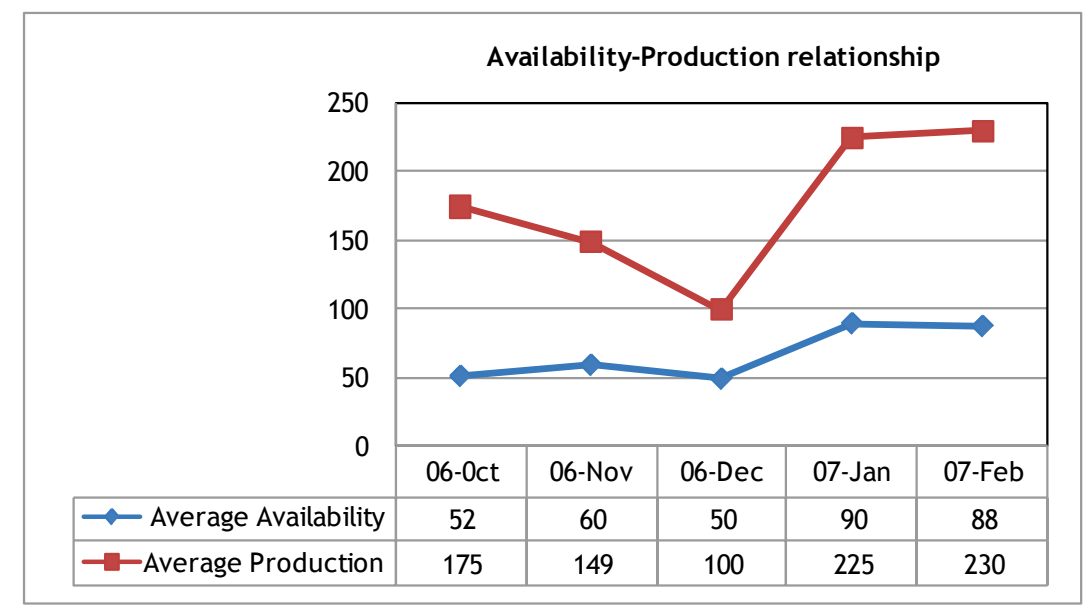

Figure 5: Availability-Production relationship 
There is a linear relationship between the availability and the production of a plant. High availability implies high production. Therefore, if all production resources are available, the plant is able to produce exceptionally well. Considering Figure 5, availability and production seem to track each other. The major concern of this project is therefore to address the cause of low availability and its implications for the process. Linear regression is used to point out the correlation between availability and plant output. The linear regression analysis shows that there is a direct correlation between increased availability and the output of tonnage produced. This reinforces the fact that any maintenance opportunities that will improve availability will improve productivity. Thus an exercise of improving availability by improving a maintenance regime through RCM is worthwhile.

The data collected for the period November 2006 to January 2007 is used in this analysis. Data for this period was considered for use because it was accurately captured and therefore could be relied upon. Figures 6 and 7 below show a high degree of scatter. This indicates poor levels of control, and thus - once corrected - potential for revenue gains. In November and December 2006, the collected data revealed that breakdown maintenance was being practised at the plant. In the beginning of January 2007, the maintenance strategies were a mixture of breakdown maintenance and preventive maintenance. This is highlighted by the low levels of scatter, suggesting that there were some levels of control in the system. Preventive maintenance began to be integrated into the maintenance strategy in January 2007. The cumulative sum (CUSUM) of tonnage output for the three months is shown in Figures 9, 10, and 11. CUSUM represents the difference between the base line (expected) and actual production over a base line period of time. The expected production is calculated using equations obtained from linear regression analysis. The following relationship was used, relating availability and production.

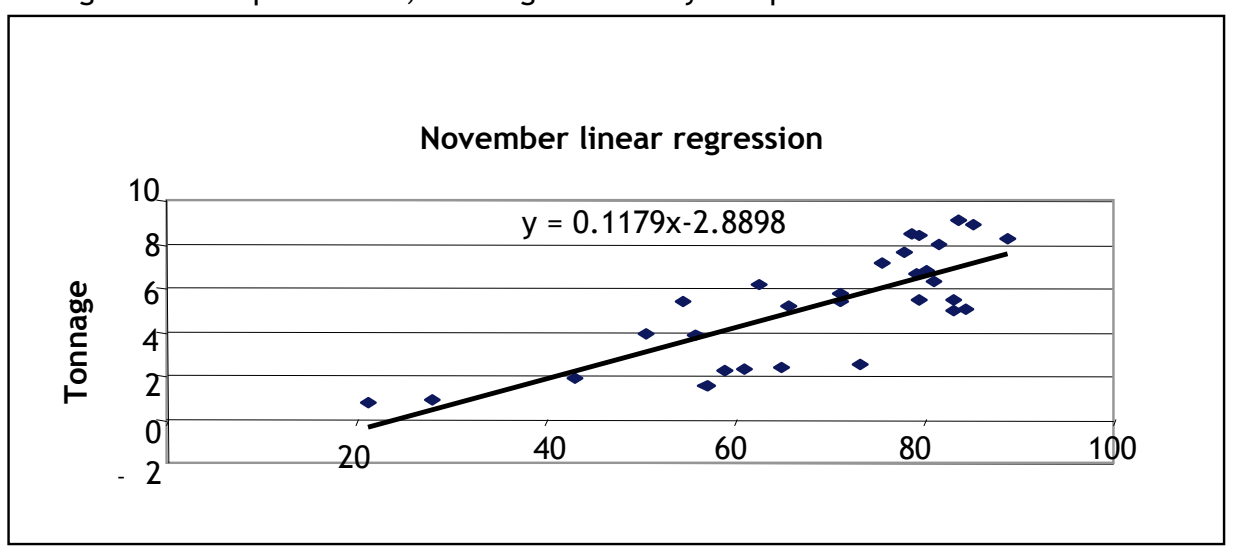

Figure 6: November 2006 regression analysis

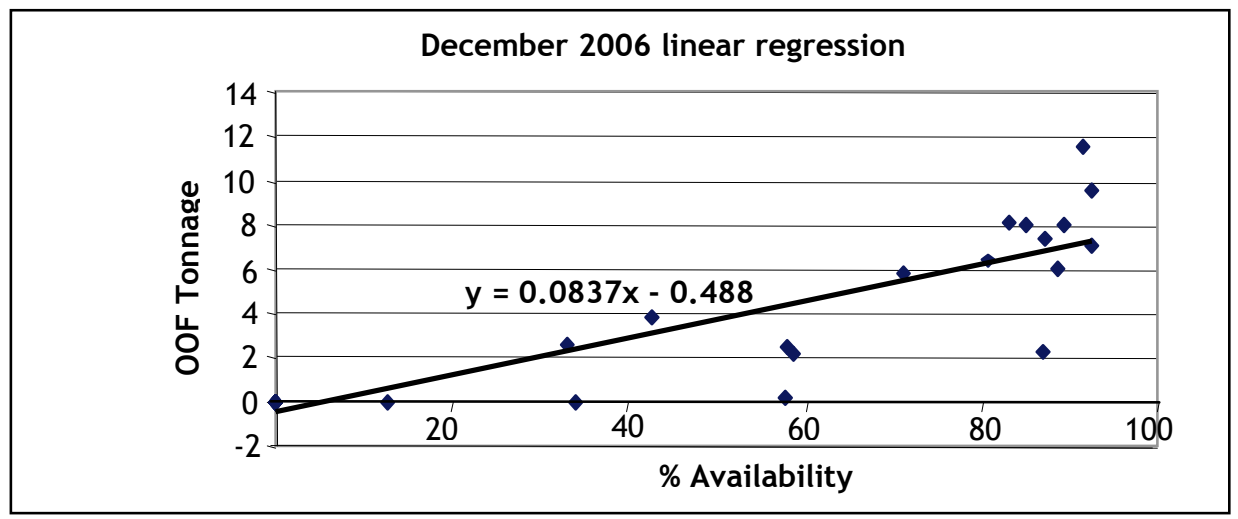

Figure 7: December 2006 linear regression analysis 


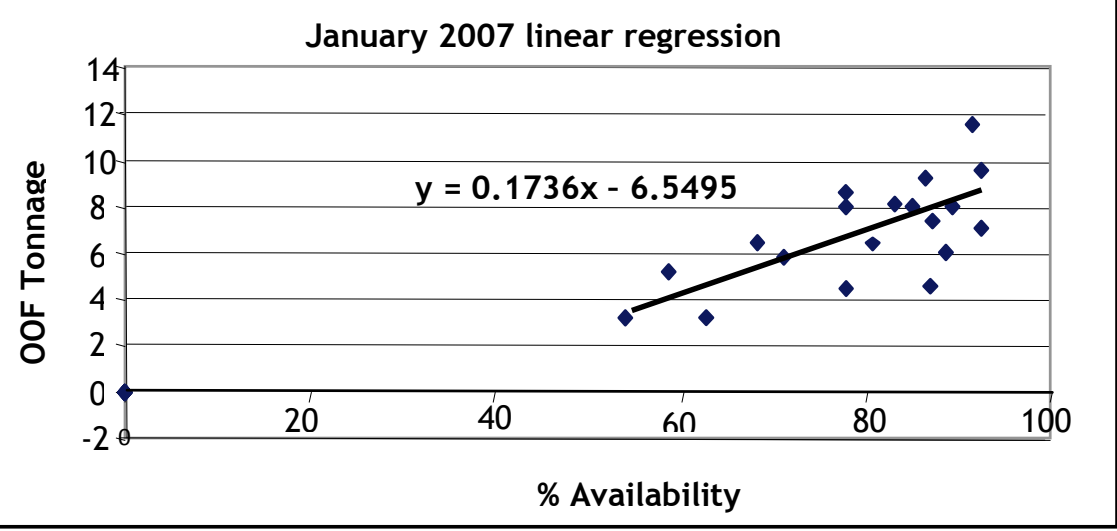

Figure 8: January 2007 linear regression analysis

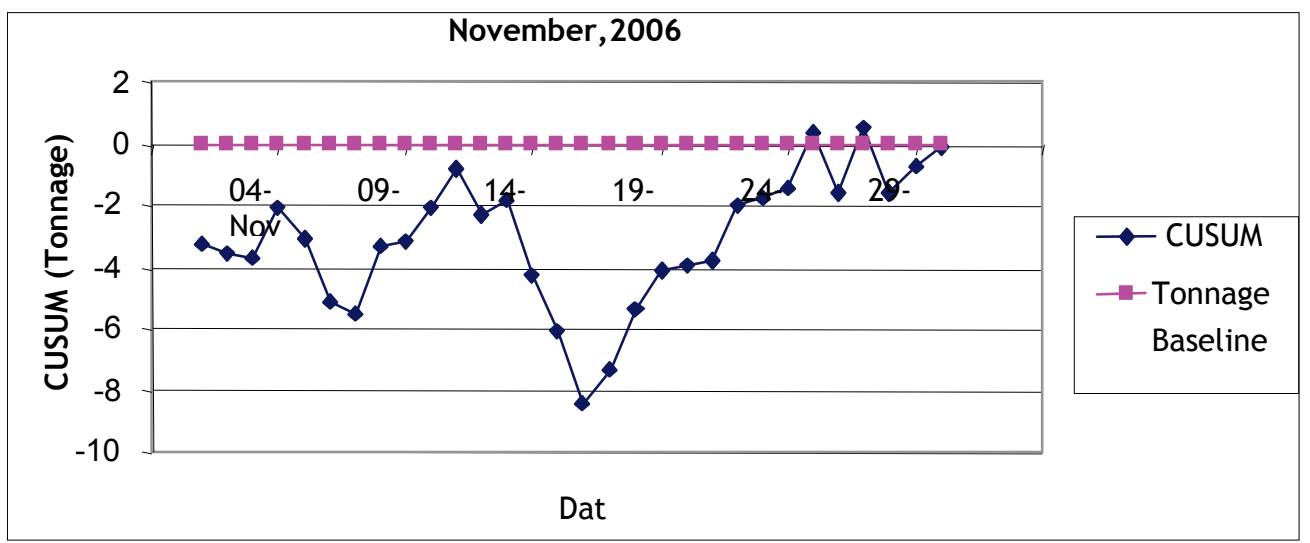

Figure 9: November 2006 CUSUM

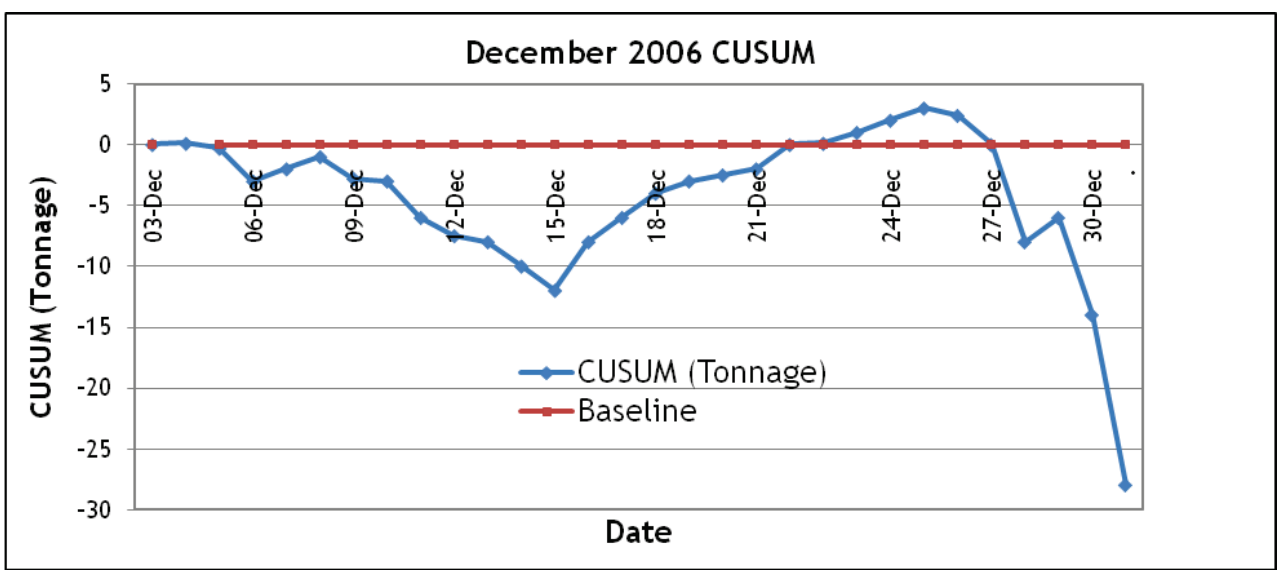

Figure 10: December 2006 CUSUM 


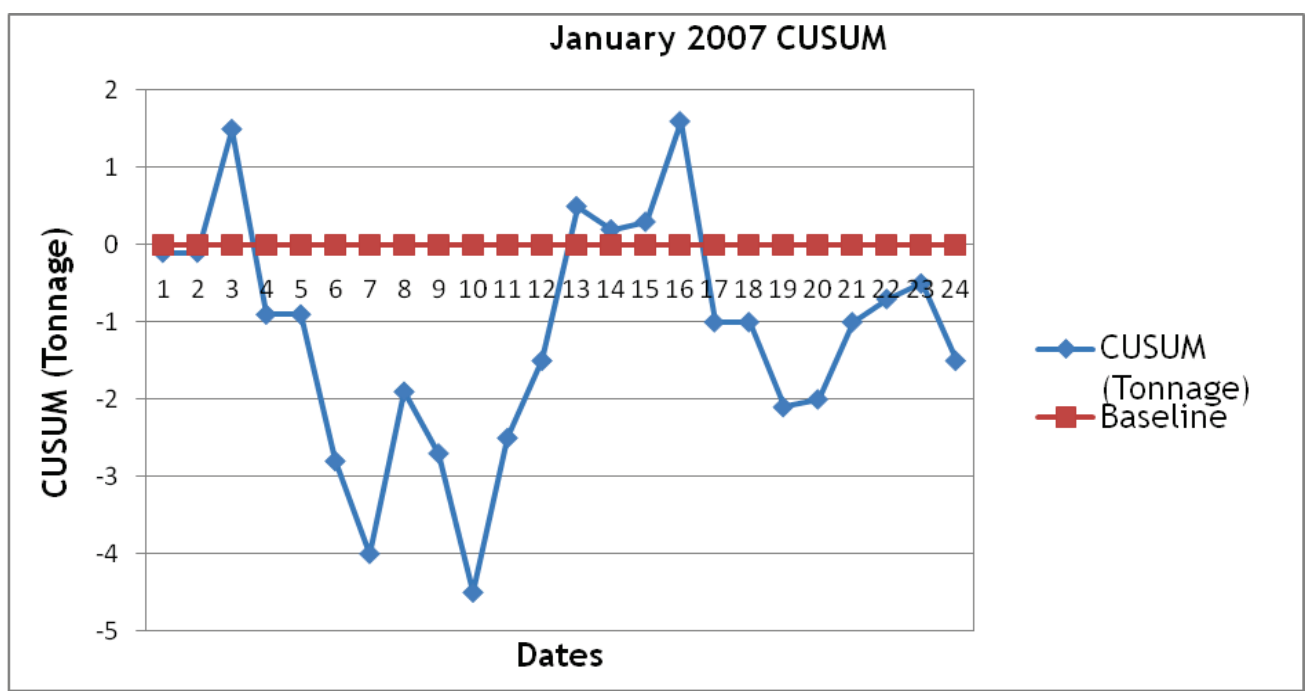

Figure 11: January 2007 CUSUM

The base line for the cumulative analysis is the zero mark. The plant performance for November 2006 and December 2006 was very poor. There was not a time when the pattern was stable, as the lines fluctuating below the zero mark indicate. December 2006 had the worst production performance (Figure 10). The CUSUM for January 2007 (Figure 11) shows a better plant performance than in previous months, as indicated by the points above the base line. Changes in the direction of the line show the results of changing maintenance strategies in the plant.

\subsection{The cost of poor availability}

The cost of poor availability was computed for the months October 2006 to March 2007. The total cost of poor availability is the 'Cost of Doing Nothing' (CODN) on maintenance. If maintenance is not properly performed, the results are revenue losses due to the inability to produce according to expectation. The cost of poor availability is therefore a direct result of poor maintenance. The values for monthly averages shown in Table 5 were considered. The cost of poor availability for any given month is calculated in terms of revenue lost, using the following equations:

Revenue loss per month $=$ expected revenue per $\mathrm{hr} \times \mathrm{t} \times \mathrm{n} \times(1-$ availability).

where $\mathrm{n}=$ number of days in a month and $\mathrm{t}=$ running time

Expected revenue per hour $=2204.5 \times 0.6 \times$ daily production $\times$ output per hour/running time $=2204.5 \times 0.6 \times 12 \times 0.55 / 22=396.81 \mathrm{US} \$ / \mathrm{hr}$

\begin{tabular}{|l|l|}
\hline Expected daily production & 12 tonnes \\
\hline Running time & 22 hours \\
\hline Output per hour & 0.5454545 tonnes per hour \\
\hline Revenue/hour & US\$396.81 per hour \\
\hline \multicolumn{2}{|c|}{ Revenue losses } \\
\hline October & \multicolumn{1}{|}{$118,722.93$} \\
\hline November & $82,333.11$ \\
\hline December & $141,103.57$ \\
\hline January & $42,677.47$ \\
\hline February & $45,856.00$ \\
\hline March & $48,055.91$ \\
\hline
\end{tabular}

Table 5: The cost of poor availability 
Maintenance of the furnace is vital so that the plant produces according to expectations. The Cost of Doing Nothing for the period October 2006 to March 2007 was US\$478,479. CODN can be reduced by maintenance excellence. Due to the breakdown maintenance strategies employed in the months October to December 2006, the revenue losses in these months were huge. January 2007 saw a decline in lost revenue as a result of employing preventative maintenance strategies. The Cost Of Doing Something (CODS) can be computed using the production variances. CODS are therefore the expected revenue gains when maintenance excellence has been applied to the furnace. Figure 12 shows the revenue gains that could have been realised in the months October 2006 to February 2007: they amounted to US\$115,160.88, based on a revenue of US\$725,49 per tonne of alloy.

There is a need to close the gap between the Cost of Doing Nothing and the Cost of Doing Something, as shown in Figure 13. RCM is a systematic way of determining what maintenance has to be done on equipment. The RCM strategy provides the means to close the gap by ensuring that the availability of the furnace is improved. It allows for the preservation not only of the equipment but also of the functions.

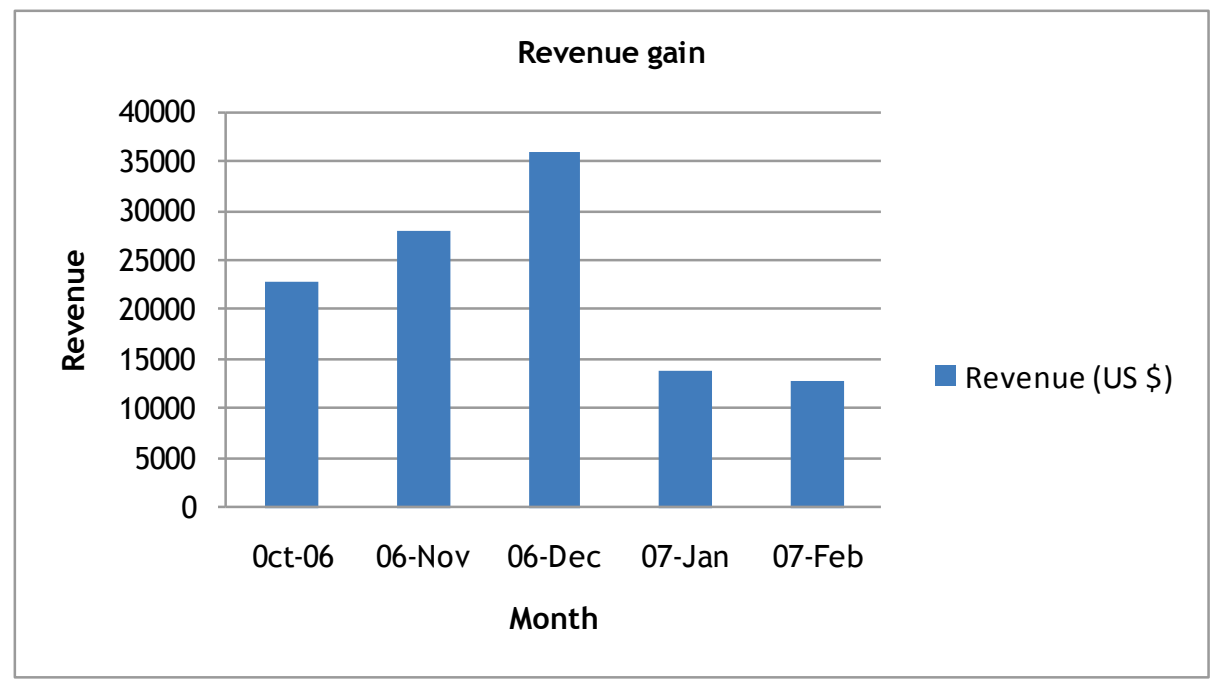

Figure 12: Expected revenue gains

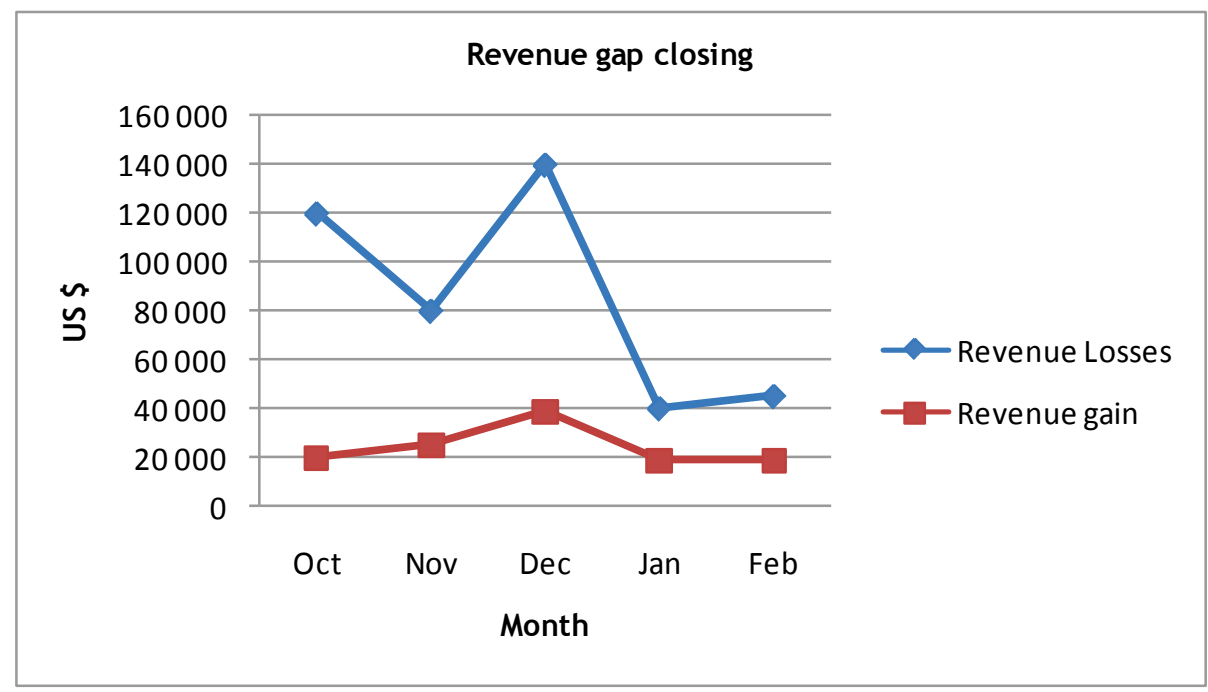

Figure13: Revenue gap closing 
In most cases maintenance work is done inappropriately, undermining the availability of equipment and hence the production capability. It is therefore imperative to embark on an RCM maintenance framework strategy in order to address the problem associated with availability, and so to obtain as much revenue from the processes as possible.

\subsection{Application of the RCM system analysis process}

The practical application of the RCM process to a system at the company in this study is considered in this section. The RCM process that was followed entails asking the seven basic RCM questions highlighted in Section 2.2.

\subsubsection{System selection and information collection}

The first step in system analysis is the selection of the system through information gathering. Assets are grouped into systems. The data on the maintenance cost for the respective systems could not be obtained, so failure records were considered for six months (October 2006 to March 2007). The systems were listed in terms of the number of failure rates. These failure rates were considered as the costs of the systems. The $A B C$ analysis was computed by listing systems in order of decreasing cost, and a percentage of the cumulative sum of the costs was considered.

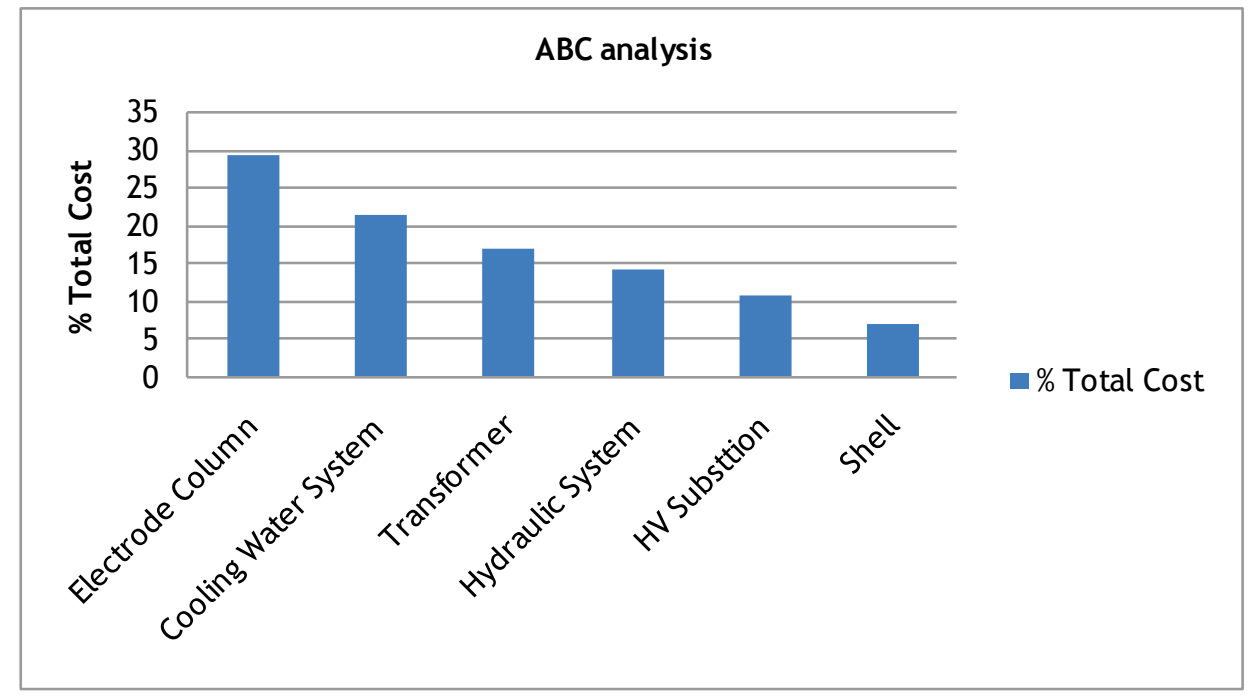

Figure 14: $A B C$ analysis

Applying the principles of $A B C$ analysis leads to the conclusion that the electrode column and the cooling water system are responsible for most of the failures, as shown in Figure 14.

\subsubsection{System boundary definition}

The system boundary definition states what has not been included in the system so that an accurate list of the components can be identified. There are three identical electrodes on the furnace. Electrode number 1 has been considered for analysis because of numerous problems with this electrode.

\subsubsection{System description}

The essential details that are needed to perform other steps are established in this step. The separate items of information developed in this step are: 


\section{RCM System Analysis}

Step 3-2 System Description / Functional Block Diagram Information: Functional lock Diagram

Plant : FURNACE 1

Plant ID: FCE 1 System ID:EC 1

System : Electrode column

Date:

Analysts: $\quad$ N. Magwaku, S. Ngwenya and A. Msipha

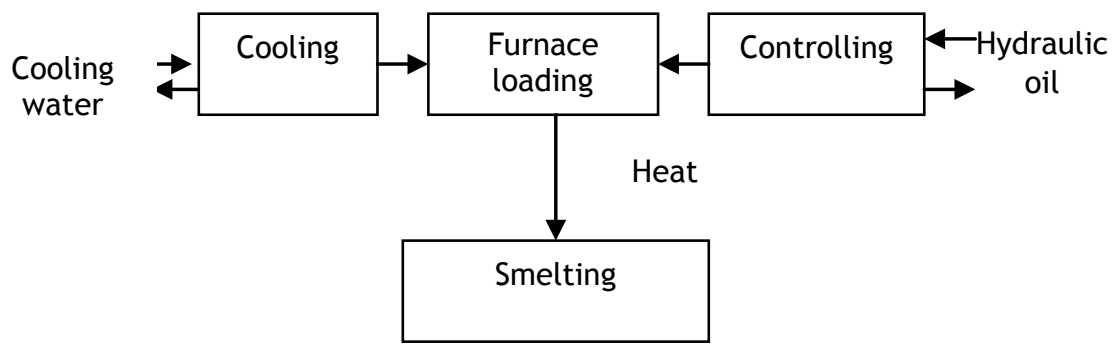

Figure 17: Functional block diagram

\section{RCM System Analysis}

Step 3-3 : System Description / Functional Block Diagram

Information: System Work Breakdown Structure

System ID: EC 1

Plant : FURNACE 1

Date:

System : Electrode column

Analysts : N. Magwaku, S. Ngwenya and A. Msipha

\begin{tabular}{|c|c|c|c|}
\hline Component & Component Description & Type & Quantity \\
\hline 1. & Power head & Non-instrumental & 1 \\
\hline 2. & $\begin{array}{l}\text { Guide roller bearings } \\
(6308 z)\end{array}$ & Non-instrumental & 4 \\
\hline 3. & Bus bars & Non-instrumental & 4 \\
\hline 4. & Bus tubes & Non-instrumental & 4 \\
\hline 5. & Key plate & Non-instrumental & 4 \\
\hline 6. & Power clamp & Non-instrumental & 4 \\
\hline 7. & Electrode clamp & Non-instrumental & 2 \\
\hline
\end{tabular}

Figure 18: System work breakdown structure 


\section{Step 3-4 : Equipment history}

Table 6 below illustrates the failure modes and causes obtained from the historical maintenance records.

\begin{tabular}{|r|l|l|l|}
\hline $\begin{array}{l}\text { Fn } \\
\text { \# }\end{array}$ & Component & Failure mode & Failure cause \\
\hline 1. & Power head & Overload & Arcing \\
\hline 2. & Guide roller bearings 6308z & Overheating, seized & $\begin{array}{l}\text { Imbalance, } \\
\text { misalignment }\end{array}$ \\
\hline 3. & Bus bars & $\begin{array}{l}\text { Overstressing, low } \\
\text { loading, out of position }\end{array}$ & Arcing, aging \\
\hline 4. & Bus tubes & Leaks, loose fitting & $\begin{array}{l}\text { Corrosion, high } \\
\text { pressure }\end{array}$ \\
\hline 5. & Key plate & Overstressing & Arcing \\
\hline 6. & Power clamp & Out of position, bent & Arcing, overheating \\
\hline 7. & Electrode clamp & Leaks, low loading & Aging \\
\hline 8. & Pad bolts & Broken, bent & Overheating \\
\hline
\end{tabular}

Table 6: Equipment history

\subsubsection{System functions and functional failures}

The information developed in steps 1 to 3 is then used to describe the functional failures of the different components, as illustrated in Table 7.

\subsubsection{Failure mode and effect analysis (FMEA)}

The functional failures for each component were analysed, and the components that were considered for RCM were determined. Table 8 below illustrates the results of the FMEA. The functions were linked to the failure modes and effects.

\begin{tabular}{|c|l|l|l|}
\hline Fn \# & Component & FUNCTION & FUNCTIONAL FAILURE \\
\hline 1. & Power head & $\begin{array}{l}\text { It receives electric current from the } \\
\text { transformer through flex cables and conducts } \\
\text { it to the rest of the components }\end{array}$ & $\begin{array}{l}\text { Fails to load the } \\
\text { furnace }\end{array}$ \\
\hline 2. & $\begin{array}{l}\text { Guide roller } \\
\text { bearings } \\
(6308 z)\end{array}$ & $\begin{array}{l}\text { Permit the movement of the electrodes up and } \\
\text { down the column }\end{array}$ & $\begin{array}{l}\text { Fail to slip the } \\
\text { electrodes }\end{array}$ \\
\hline 3. & Bus bars & $\begin{array}{l}\text { Conduct the electrical charge from the power } \\
\text { head to the clamps }\end{array}$ & Fail to load the furnace \\
\hline 4. & Bus tubes & $\begin{array}{l}\text { Transport cooling water from the tubes to the } \\
\text { contact pads for cooling }\end{array}$ & $\begin{array}{l}\text { Fail to cool the contact } \\
\text { pads }\end{array}$ \\
\hline 5. & Key plate & Holds bus bars in position & $\begin{array}{l}\text { Bends the bus bars } \\
\text { causing misalignment }\end{array}$ \\
\hline 6. & Power clamp & Holds bus tubes in position & $\begin{array}{l}\text { Fails to produce an arc } \\
\text { in the charge }\end{array}$ \\
\hline 7. & $\begin{array}{l}\text { Electrode } \\
\text { clamp }\end{array}$ & Conducts the electric charge to the blend & $\begin{array}{l}\text { Fail to produce an arc, } \\
\text { therefore low loading } \\
\text { the furnace }\end{array}$ \\
\hline 8. & Pad bolts & Hold the electrode clamps in position & \\
\hline
\end{tabular}

Table 7: Functions and functional failure description 


\begin{tabular}{|c|c|c|c|c|c|c|c|}
\hline \multirow{2}{*}{ FF\# } & \multirow{2}{*}{$\begin{array}{c}\text { Comp. } \\
\text { description }\end{array}$} & \multirow{2}{*}{$\begin{array}{c}\text { Failure } \\
\text { mode }\end{array}$} & \multirow{2}{*}{$\begin{array}{c}\text { Failure } \\
\text { cause }\end{array}$} & \multicolumn{4}{|c|}{ Failure effect } \\
\hline & & & & Local & System & Plant & LTA \\
\hline 1. & Power head & Overload & Arcing & $\begin{array}{c}\text { Unstable } \\
\text { operations }\end{array}$ & $\begin{array}{l}\text { Variable } \\
\text { current }\end{array}$ & $\begin{array}{l}\text { Cannot load } \\
\text { the furnace }\end{array}$ & $Y$ \\
\hline 2. & $\begin{array}{c}\text { Guide roller } \\
\text { bearings } \\
\text { (6308z) }\end{array}$ & $\begin{array}{l}\text { Over- } \\
\text { heating, } \\
\text { seized }\end{array}$ & $\begin{array}{l}\text { Imbalance, } \\
\text { misalignment }\end{array}$ & $\begin{array}{c}\text { Condition } \\
\text { of bearings } \\
\text { deteriorates }\end{array}$ & $\begin{array}{l}\text { Erratic } \\
\text { response to } \\
\text { slipping } \\
\text { undermined } \\
\text { electrode } \\
\text { length }\end{array}$ & $\begin{array}{l}\text { Poor taping } \\
\text { conditions, } \\
\text { therefore } \\
\text { poor quality } \\
\text { product }\end{array}$ & $\mathrm{Y}$ \\
\hline 3. & Bus bars & $\begin{array}{l}\text { Overstres- } \\
\text { sing, low } \\
\text { loading, } \\
\text { out of } \\
\text { position }\end{array}$ & Arcing, aging & Vibrations & & $\begin{array}{l}\text { No furnace } \\
\text { load, arcs }\end{array}$ & $\mathrm{Y}$ \\
\hline 4. & Bus tubes & $\begin{array}{l}\text { Leaks, } \\
\text { loose } \\
\text { fitting }\end{array}$ & $\begin{array}{c}\text { Corrosion, } \\
\text { high pressure }\end{array}$ & $\begin{array}{l}\text { Failure to } \\
\text { hold } \\
\text { pressure }\end{array}$ & $\begin{array}{l}\text { Failure to } \\
\text { cool the } \\
\text { contact pads }\end{array}$ & Overheating & $Y$ \\
\hline 5. & Key plate & $\begin{array}{l}\text { Overstres- } \\
\text { sing }\end{array}$ & Arcing & & & $\begin{array}{c}\text { Reduced yield } \\
\text { throughput }\end{array}$ & $Y$ \\
\hline 6. & Power clamp & $\begin{array}{l}\text { Out of } \\
\text { position, } \\
\text { bent }\end{array}$ & $\begin{array}{c}\text { Arcing, } \\
\text { overheating }\end{array}$ & & & & Y \\
\hline 7. & $\begin{array}{l}\text { Electrode } \\
\text { clamp }\end{array}$ & $\begin{array}{c}\text { Leaks, low } \\
\text { loading }\end{array}$ & Aging & & Cannot load & \begin{tabular}{|c|} 
Poor taping \\
conditions, \\
poor product \\
quality, \\
electrode \\
fractures
\end{tabular} & Y \\
\hline 8. & Pad bolts & $\begin{array}{c}\text { Broken, } \\
\text { bent }\end{array}$ & Overheating & & & Low loading & $Y$ \\
\hline
\end{tabular}

Table 8 : Failure mode and effect analysis

\subsubsection{The logic tree}

The failure modes obtained in the above sections will be subjected to the RCM logic tree, as shown in Figure 19. The logic tree is a graphical method of describing the combination of events leading to a defined system failure. The reliability-centred maintenance (RCM) decision logic tree is used to determine the maintenance approach for the equipment item or system. 


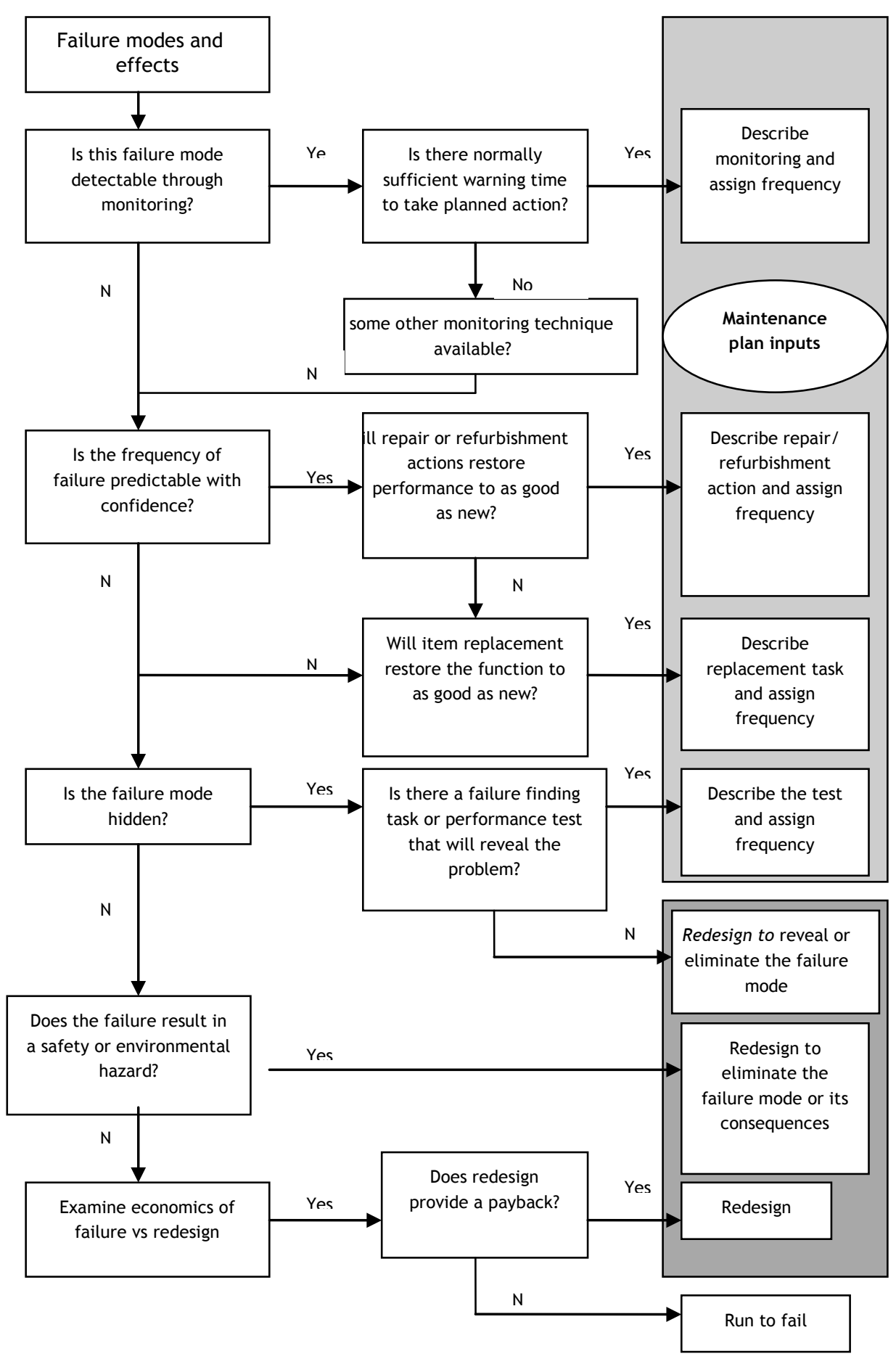

Figure 19: RCM decision logic (adapted from Campbell, 1999) [12]. 
The recommended maintenance strategies for the various components are as shown in Table 9 and 10:

\begin{tabular}{|c|c|c|c|c|c|c|c|c|c|}
\hline & $\begin{array}{c}\text { Comp } \\
\#\end{array}$ & $\begin{array}{l}\text { Component } \\
\text { description }\end{array}$ & $\begin{array}{c}\text { FM } \\
\#\end{array}$ & $\begin{array}{l}\text { Failure } \\
\text { mode }\end{array}$ & Evident & Safety & Outage & Category & Comment \\
\hline 1.1 & 01 & Power head & 0101 & Overload & Yes & No & Yes & B & $\begin{array}{l}\text { Very costly, } \\
\text { must be } \\
\text { available at } \\
\text { all costs }\end{array}$ \\
\hline 1.2 & 01 & $\begin{array}{l}37 \mathrm{~kW} \\
\text { Electric } \\
\text { motor }\end{array}$ & 0102 & $\begin{array}{l}\text { Motor } \\
\text { cannot } \\
\text { start }\end{array}$ & Yes & No & Yes & B & $\begin{array}{l}\text { Must always } \\
\text { be functional }\end{array}$ \\
\hline 1.3 & 01 & $\begin{array}{l}\text { V-grooved } \\
\text { pulley }\end{array}$ & 0103 & $\begin{array}{l}\text { Broken / } \\
\text { cracked } \\
\text { pulley }\end{array}$ & Yes & No & Yes & B & $\begin{array}{l}\text { Can lead to } \\
\text { drive failure }\end{array}$ \\
\hline 1.4 & 02 & $\begin{array}{c}\text { Guide roller } \\
\text { bearing }\end{array}$ & 0104 & $\begin{array}{l}\text { Over- } \\
\text { heating; } \\
\text { seizing }\end{array}$ & Yes & No & Yes & B & $\begin{array}{l}\text { Main concern } \\
\text { is failure of } \\
\text { bearing to } \\
\text { fulfil function }\end{array}$ \\
\hline 1.5 & 02 & $\begin{array}{l}\text { V-grooved } \\
\text { pulley }\end{array}$ & 0105 & $\begin{array}{c}\text { Groove } \\
\text { surface } \\
\text { deteriora- } \\
\text { tion }\end{array}$ & Yes & No & No & C & $\begin{array}{c}\text { Can shorten } \\
\text { belt life }\end{array}$ \\
\hline 1.6 & 03 & Bus bars & 0106 & $\begin{array}{l}\text { Overstress- } \\
\text { ing, low } \\
\text { loading, } \\
\text { out of } \\
\text { position } \\
\end{array}$ & Yes & No & Yes & $D / C$ & $\begin{array}{c}\text { Causes } \\
\text { misalignment }\end{array}$ \\
\hline 1.7 & 04 & Bus tubes & 0107 & $\begin{array}{l}\text { Leaks, } \\
\text { loose } \\
\text { fitting }\end{array}$ & Yes & No & Yes & B & $\begin{array}{l}\text { Can be costly } \\
\text { for production }\end{array}$ \\
\hline 1.8 & 05 & Key plate & 0108 & $\begin{array}{l}\text { Overstress- } \\
\text { ing }\end{array}$ & Yes & No & No & C & $\begin{array}{l}\text { Main concern } \\
\text { is motor's } \\
\text { failure to } \\
\text { start }\end{array}$ \\
\hline 1.9 & 06 & $\begin{array}{l}\text { Power } \\
\text { clamp }\end{array}$ & 0109 & $\begin{array}{l}\text { Out of } \\
\text { position, } \\
\text { bent }\end{array}$ & Yes & No & No & C & $\begin{array}{c}\text { Can be costly } \\
\text { for } \\
\text { production, } \\
\text { should be } \\
\text { avoided } \\
\end{array}$ \\
\hline 1.10 & 07 & $\begin{array}{l}\text { Electrode } \\
\text { clamp }\end{array}$ & 0110 & Stuck & Yes & No & Yes & C & $\begin{array}{c}\text { Can slow } \\
\text { production }\end{array}$ \\
\hline 1.11 & 08 & Pad bolts & 0111 & $\begin{array}{c}\text { Broken, } \\
\text { bent }\end{array}$ & Yes & No & Yes & B & $\begin{array}{l}\text { Can lead to } \\
\text { production } \\
\text { disturbances }\end{array}$ \\
\hline
\end{tabular}

Table 9: Logic tree analysis failure mode criticality

\subsubsection{Task selection}

The RCM system analysis effort to this point was directed at delineating those failure modes where a PM task will give the biggest return for the investment to be made. Step 7 tests failure modes for applicability and effectiveness, using the task selection roadmap. This was highly useful in logically developing the candidate PM tasks for each failure mode. The output of this analysis is summarised in Table 10. 
N/B: TD: Time-directed; TDI: Time-directed intrusive; TDN: Time-directed non-intrusive; $\mathrm{CD}$ : Condition directed

FF: Failure finding; RTF: Run to failure

\begin{tabular}{|c|c|c|c|c|c|c|c|}
\hline 葉 & 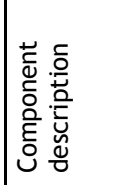 & 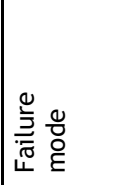 & 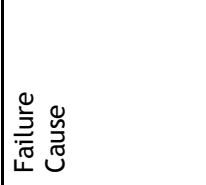 & 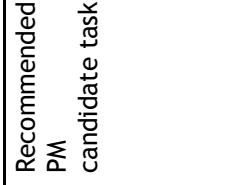 & 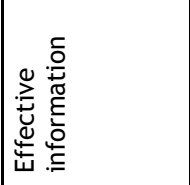 & 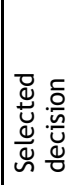 & 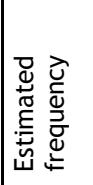 \\
\hline 1.1 & $\begin{array}{l}\text { Power } \\
\text { Head }\end{array}$ & Overload & Burnt motor & $\begin{array}{l}\text { 1. Vibration } \\
\text { monitoring }(C D) \\
\text { 2. Periodically } \\
\text { check condition } \\
\text { 3.RTF } \\
\end{array}$ & $\begin{array}{l}\text { 2. Is the most } \\
\text { effective way }\end{array}$ & $C D$ & Yearly \\
\hline 1.2 & $\begin{array}{l}37 \mathrm{~kW} \\
\text { electric } \\
\text { motor }\end{array}$ & $\begin{array}{l}\text { Motor } \\
\text { cannot } \\
\text { start }\end{array}$ & $\begin{array}{l}\text { System locked, } \\
\text { no power supply }\end{array}$ & \begin{tabular}{|l|} 
1. Periodically \\
check power \\
supply system (TD) \\
2. RTF \\
\end{tabular} & \begin{tabular}{|l} 
1. Equipment \\
history \\
indicates no \\
such failure \\
\end{tabular} & RTF & \\
\hline 1.3 & $\begin{array}{l}\text { V-grooved } \\
\text { pulley }\end{array}$ & $\begin{array}{l}\text { Broken/ } \\
\text { cracked } \\
\text { pulley }\end{array}$ & Age / wear-out & $\begin{array}{l}\text { 1. Periodically } \\
\text { check pulley } \\
\text { condition (TD) } \\
\text { 2. RTF } \\
\end{array}$ & $\begin{array}{l}\text { 2. RTF is the } \\
\text { only practical } \\
\text { option }\end{array}$ & RTF & \\
\hline 1.4 & $\begin{array}{l}\text { Guide } \\
\text { roller }\end{array}$ & $\begin{array}{l}\text { Over- } \\
\text { heating/ } \\
\text { seized }\end{array}$ & \begin{tabular}{|l} 
Lubrication \\
deficiency, \\
fatigue, \\
imbalance, \\
misalignment \\
\end{tabular} & \begin{tabular}{|l|} 
1. Monitor temp \\
(CD) \\
2. Check for \\
bearing condition \\
and lubricate (TD) \\
\end{tabular} & $\begin{array}{l}\text { 2. Is the most } \\
\text { effective } \\
\text { option }\end{array}$ & TDI & $\begin{array}{l}18 \\
\text { months }\end{array}$ \\
\hline 1.5 & $\begin{array}{l}\text { V-grooved } \\
\text { pulley }\end{array}$ & $\begin{array}{l}\text { Groove } \\
\text { surface } \\
\text { deteriora- } \\
\text { tion }\end{array}$ & $\begin{array}{l}\text { Corrosion/ } \\
\text { debris causing } \\
\text { abrasion }\end{array}$ & $\begin{array}{l}\text { 1. Periodically } \\
\text { remove and check } \\
\text { pulley condition } \\
\text { (TD) } \\
\text { 2. RTF }\end{array}$ & \begin{tabular}{|l} 
2. RTF is not \\
preferable \\
because it \\
causes \\
secondary \\
damage \\
\end{tabular} & TDI & $\begin{array}{l}6 \\
\text { months }\end{array}$ \\
\hline 1.6 & Bus bars & $\begin{array}{l}\text { Over- } \\
\text { stressing/ } \\
\text { low load }\end{array}$ & $\begin{array}{l}\text { Age / not } \\
\text { properly } \\
\text { installed }\end{array}$ & $\begin{array}{l}\text { 1. periodically } \\
\text { check condition } \\
\text { (TD) } \\
\text { 2. RTF } \\
\end{array}$ & $\begin{array}{l}\text { 1. It causes } \\
\text { less secondary } \\
\text { damage }\end{array}$ & TDI & Yearly \\
\hline 1.7 & Bus tubes & \begin{tabular}{|l|} 
Leaks / \\
loose \\
fitting \\
\end{tabular} & $\begin{array}{l}\text { Lubrication } \\
\text { deficiency; age; } \\
\text { excessive thrust }\end{array}$ & $\begin{array}{l}\text { 1. Listen for } \\
\text { increase in noise } \\
\text { level (CD) } \\
\end{array}$ & $\begin{array}{l}\text { It is the most } \\
\text { effective way }\end{array}$ & $C D$ & $\begin{array}{l}6 \\
\text { months }\end{array}$ \\
\hline 1.8 & Key plate & $\begin{array}{l}\text { Over- } \\
\text { stressing }\end{array}$ & $\begin{array}{l}\text { Loose holding } \\
\text { screws }\end{array}$ & $\begin{array}{l}\text { 1. RTF } \\
\text { 2.Check level to } \\
\text { ensure screw } \\
\text { tightness (FF) }\end{array}$ & $\begin{array}{l}\text { 2. Is the most } \\
\text { applicable }\end{array}$ & FF & $\begin{array}{l}2 \\
\text { weeks }\end{array}$ \\
\hline 1.9 & $\begin{array}{l}\text { Power } \\
\text { clamp }\end{array}$ & \begin{tabular}{|l} 
Out of \\
position/ \\
bent \\
\end{tabular} & $\begin{array}{l}\text { Broken / loose } \\
\text { holding bolts }\end{array}$ & $\begin{array}{l}\text { 1.RTF } \\
\text { 2.Check tightness } \\
\text { of bolts } \\
\end{array}$ & $\begin{array}{l}\text { 2. is the most } \\
\text { effective }\end{array}$ & FF & $\begin{array}{l}2 \\
\text { weeks }\end{array}$ \\
\hline 1.10 & $\begin{array}{l}\text { Electrode } \\
\text { clamp }\end{array}$ & Stuck & \begin{tabular}{|l} 
Seized \\
interlinking \\
bearing \\
\end{tabular} & $\begin{array}{l}\text { 1. Check bearing } \\
\text { condition } \\
\text { 2. RTF } \\
\end{array}$ & $\begin{array}{l}\text { 1. Most } \\
\text { effective }\end{array}$ & $C D$ & $\begin{array}{l}6 \\
\text { months }\end{array}$ \\
\hline 1.11 & Pad bolts & $\begin{array}{l}\text { Bent / } \\
\text { broken }\end{array}$ & Over-heating & $\begin{array}{l}\text { 1. Remove, inspect, } \\
\text { and clean; } \\
\text { 2.Monitor valve } \\
\text { temp (CD) }\end{array}$ & \begin{tabular}{|l|} 
Sensitive valve \\
cannot open \\
without \\
specialised \\
equipment. \\
\end{tabular} & RTF & - \\
\hline
\end{tabular}

Table 10: RCM task analysis output 
Availability after the implementation of the PM options is shown in Table 11 below. The table shows an improvement in availability to an average of $84 \%$ for the period October 2007 to March 2008. These results show an improvement; but it should be pointed out that there is the possibility of an even higher availability, given that some recommended PM task were to be implemented over a longer cycle time, as highlighted in Table 10.

\begin{tabular}{|c|c|c|c|c|c|c|c|c|}
\hline \multirow{2}{*}{$\begin{array}{c}\text { Month/ } \\
2007-2008\end{array}$} & \multicolumn{5}{|c|}{ \% Availability } & \multirow{2}{*}{ STD } & \multirow{2}{*}{ 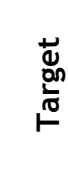 } & \multirow{2}{*}{ 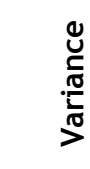 } \\
\hline & $\begin{array}{l}\text { Week } \\
1\end{array}$ & $\begin{array}{l}\text { Week } \\
2\end{array}$ & $\begin{array}{l}\text { Week } \\
3\end{array}$ & $\begin{array}{l}\text { Week } \\
4\end{array}$ & Average & & & \\
\hline October & 75.21 & 76.87 & 79.87 & 70.55 & 75.63 & 7.90 & \multirow{7}{*}{$85 \%$} & 62.41 \\
\hline November & 77.35 & 79.2 & 78.79 & 76.39 & 78.13 & 5.39 & & 29.09 \\
\hline December & 81.11 & 78.13 & 79.56 & 84.56 & 80.84 & 2.68 & & 7.18 \\
\hline January & 85.69 & 86.01 & 88.22 & 87.33 & 86.81 & 3.29 & & 10.84 \\
\hline February & 87.58 & 86.74 & 89.28 & 91.34 & 88.74 & 5.22 & & 27.20 \\
\hline March & 88.55 & 93.76 & 89.32 & 92.19 & 90.96 & 7.44 & & 55.28 \\
\hline \multicolumn{5}{|c|}{ MEAN AVERAGE } & 83.52 & & & \\
\hline
\end{tabular}

Table 11: Availability after RCM, PM implementation

\section{CONCLUSION AND RECOMMENDATIONS}

The aim of this paper was to develop an RCM model for improving plant availability. Availability is considered a vital part of any production unit. The research noted that maintenance is often neglected. However, as Willmott [22] argues, the maintenance goal is also to offer a company competitive advantage. However, RCM provides a way to close the gap between the cost of doing nothing and the cost of doing something through optimising the maintenance function, by objectively specifying the preventive maintenance tasks. RCM uses strictly defined steps with procedures to come up with an auditable and measurable output.

\section{- To increase availability}

As seen from the results in Table 11, the introduction of preventive maintenance strategies specified in Table 10 saw an increase in availability to an average of $84 \%$. RCM enables a critical analysis of the equipment using FMEA. The involvement of the operators of equipment in the RCM review groups means an established level of control, as well as the operational requirements of the equipment, thus ensuring a decrease in downtime. According to Koshal [21], there is an optimum point for availability. As the availability approaches $100 \%$, downtime decreases and inevitably maintenance costs increase.

- To increase production from $\mathbf{1 8 0}$ to $\mathbf{3 0 0}$ tonnes of alloy per month

An increase in availability ensures an increase in production. Instead of 5-6 loads being produced per month, the production shifted to 8 loads per month. Instead of nine ingots, production shifted to 15 ingots per day.

- To reduce maintenance costs by $20 \%$ of the total manufacturing costs

Once RCM has been established, it is easy to determine the critical plant equipment using the $A B C$ analysis. The maintenance spare parts inventory is optimised, thus reducing the cost incurred by panic operating conditions. RCM enables planning of all tasks, reducing the overtime costs that contribute to maintenance costs. RCM can therefore be applied to SMEs like Oliken Ferro-Alloys. The company is still to get to world class standards (WCS).

\subsection{Recommendations}

The following recommendations are made: 
1. The RCM process is very disciplined and logical: without training it can prove difficult. The competence and skills among the RCM team members are insufficient; therefore further training should be arranged. The team should also be motivated to carry out the task at hand and to improve their interest in doing the work. Sufficient time should be allocated to the team so that they can perform the analysis of all the equipment accurately.

2. Restructure stores and employ a qualified individual who is responsible for the maintenance stores so that the plant spares inventory is optimised.

3. Use controlled measurement techniques such as Age Exploration. The maintenance asset register needs to be updated from time to time, and to have a policy to consider equipment write-off periods, as some of the equipment is difficult and costly to maintain.

4. Implement preventive maintenance, and apply RCM to all plant equipment.

5. Consider the Six Sigma approach, and use DMAIC: Define, Measure, Analyse, Improve, and Control.

Nair [23] mentioned that a maintenance policy has a direct bearing on the efficiency and economy of the plant. Better maintenance makes production operations management less costly. Poor maintenance on the other hand causes frequent breakdowns, interruptions on the production line, and inferior product quality. Ingalls [24] also states that the effective operation of the maintenance function depends significantly on the maintenance of the organisational structure. Kelly [25] comments that, since the organisational structure controls the manpower, the hierarchy of communications, and maintenance resource allocation with the right capabilities in the right maintenance areas, are essential.

This paper demonstrated the effectiveness of RCM in identifying the most appropriate and cost effective maintenance regime without any detrimental effect on safety, availability, or economic impact. This was achieved through demonstrating the mechanics of implementing RCM on a selected system of the case study in question. The addition, deletion, and redefinition of tasks were justified, all in a structured manner, with the net desired result being greater equipment availability at a significantly lower cost. It should be pointed out, however, that the maintenance of physical assets can no longer be treated as an 'engineering problem'. The competitive environment in which business operates requires an approach that integrates the operational objectives of the business and the life-cycle objectives of the physical assets.

\section{REFERENCES}

[1] Ahmad, M. \& Benson, R. 2007. Benchmarking in the process industry, IChem ${ }^{\mathrm{E}}$, UK.

[2] Miller, J.A. 1992. Measuring progress through benchmarking, CMA Magazine, Vol 66 No.4, p37.

[3] Wilson, A. 1999. Asset management and maintenance strategy, Maintenance and Asset Management, Vol. 14 No.1, pp.3-10.

[4] Kutucuoglu, K.Y., Hamali, J., Iran, I. \& Sharp, J.M. 2001. A framework for managing maintenance using performance measurements systems, International Journal of Operations \& Production Management, Vol. 21 No.1, pp.173-195.

[5] Heiser, J. \& Render, B. 2008. Operations management, Prentice Hall.

[6] Tsang, A.H.C., Jardine, A.K.S. \& Kolodny, H. 1999. Measuring maintenance performance: a holistic approach, International Journal of Operations \& Production Management, Vol. 19 No.7, pp.691-715.

[7] Smith, D.J. 2005. Reliability, maintainability and risk: Practical methods for engineers including RCM and safety-related systems, Butterworth Heinemann.

[8] Moubray, J. 1997. Reliability-Centered Maintenance II, $2^{\text {nd }}$ edition, ButterworthHeinemann, Oxford.

[9] IEC 60300-3-11, 1999. Application Guide RCM, International Electro-Technical Commission, Geneva.

[10] Dunn, A. 1996, A framework for achieving best practice in maintenance. www.eef.org.uk 
[11] Nowlan, F.S. \& Heap, H. 1978, Reliability-Centred Maintenance, Technical Information Service, US Department of Commerce, Springfield, VA.

[12] Sutton, I.S. 1995. Integrated Management System Improvement plant Reliability, Journal of Hydrocarbon Processing, Vol. 74 No.1, pp 63-66.

[13] Rausand M. 1998. Reliability Centred Maintenance, Journal of Reliability Engineering and System Safety, Vol. 60 No. 2, pp 121-132.

[14] Campbell J.D. 1999. The Reliability Handbook - Plant engineering and maintenance, Volume 23, Clifford/ Elliot Publications.

[15] Smith, A.M. 1993. Reliability Centred Maintenance, McGraw Hill Inc, New York.

[16] Bowler, D.J \& Leonard R. 1994. Evaluating the intangible benefits of RCM, Leadership \& Organisation Development Journal, Vol. 9 No.4, pp 17-20.

[17] Smith, A. \& Hinchcliffe, G. 2004. RCM: Gateway to world class maintenance, Elsevier, Butterworth Heinemann.

[18] Moubray, J. 1992. Reliability-Centred Maintenance, $4^{\text {th }}$ edition, ButterworthHeinemann, Oxford.

[19] Murty, A.S.R. \& Naikan V.N.A. 1995. Availability and maintenance cost optimisation of a production plant, International Journal of Quality \& Reliability Management, Vol. 12 No. 2, pp. 28-35, MCB UP Ltd, ISSN 0265-671X.

[20] Patton, J.D. 1994. Maintainability and maintenance management, $3^{\text {rd }}$ edition, Instrument Society of America.

[21] Koshal, D. 1993. Manufacturing engineer's handbook, Butterworth Heinemann.

[22] Willmott, P. 1994. TPM the Western way, Butterworth-Heinemann.

[23] Nair, N.G. 2007. Production and operations management, Tata McGraw-Hill.

[24] Ingalls, P. 2000. World class maintenance (online), Total productive maintenance online, available at: www.tpmonline.com/articles_on_total_productive maintenance/tpm/newpractices.htm

[25] Kelly, A. 1997. Maintenance organisation \& systems - Business-centred maintenance, Butterworth-Heinemann, Oxford. 
http://sajie.journals.ac.za 